\title{
OBRAZ HERETYKA W LIBER APOTHEOSIS AURELIUSZA PRUDENCJUSZA KLEMENSA
}

Proces kształtowania się nauki katolickiej w okresie wczesnochrześcijańskim stanowi od wieków temat licznych badań i refleksji, nie tylko na gruncie nauk teologicznych, ale również historycznych i filologicznych. Już w pierwszych latach po śmierci Chrystusa, a więc jeszcze w czasie działalności apostołów, pojawiają się pierwsze, świadome refleksje nad otrzymanym przesłaniem Boga ${ }^{1}$. Jednym z najbardziej istotnych aspektów badań nad rozwojem doktryny chrześcijańskiej jest fakt, iż rozwijała się ona w nurcie dyskusji i polemiki, a co za tym idzie ścierania się różnych poglądów, które mniej lub bardziej odbiegały od przesłania zawartego w Piśmie Świętym. W ową polemikę wpisuje się także utwór Liber Apotheosis Aureliusza Prudencjusza Klemensa, stanowiący przykład polemicznej refleksji z heretyckimi poglądami na temat natury i boskości Chrystusa. Chociaż nie brak opracowań dotyczących chrystologii zawartej w powyższym utworze ${ }^{2}$, to jednak temat polemiki z herezjami jest pomijany.

Niniejszy artykuł stanowi próbę ukazania obrazu heretyka, jaki kształtuje w swoich utworach Aureliusz Prudencjusz Klemens. Całość podzielona została na dwa paragrafy, z których pierwszy stanowi omówienie wewnętrznej motywacji Prudencjusza do napisania dzieł polemizujących z herezjami, natomiast drugi prezentować będzie źródła herezji, które zauważa Prudencjusz, a także będzie próbą odpowiedzi na pytanie: jaki obraz heretyka kształtuje w swoim dziele poeta?

1. Okoliczności powstania dzieła. Głównym, a w zasadzie jedynym źródłem informacji o życiu i twórczości Aureliusza Prudencjusza Klemensa jest

${ }^{*}$ Mgr lic. Małgorzata Pyzik-Turska - doktorantka przy Katedrze Patrologii Greckiej i Łacińskiej w Instytucie Historii Kościoła i Patrologii na Wydziale Teologii Katolickiego Uniwersytetu Lubelskiego Jana Pawła II; e-mail: pyzik.malgorzata@gmail.com.

${ }^{1}$ Por. N. Widok, Ortodoksja, herezja, schizma - wyjaśnienie pojęć, w: Ortodoksja, herezja, schizma w Kościele starożytnym, red. F. Drączkowski - J. Pałucki - P. Szczur - M. Szram - M. Wysocki - M. Ziółkowska, Lublin 2012, 15.

${ }^{2} \mathrm{Z}$ prac na temat Liber Apotheosis należy wymienić: S.T. Collins, ,, The Apotheosis” of Prudentius, SE 9 (1957) 44-49; R.G. Rank, ,,The Apotheosis” of Prudentius. A Structural Analysis, CF 20 (1966) 18-31; L. Padovese, La cristologia di Aurelio Prudenzio Clemente, Roma 1980; C. Fabian, Dogma und Dichtung. Untersuchungen zu Prudentius ,,Apotheosis”, Frankfurt am Main 1988; G. Garuti, Prudentius Apotheosis, Modena 2005. 
Przedmowa (Praefatio) poprzedzająca zbiór jego poezji. Dowiadujemy się z niej, że w chwili pisania poematów miał on dokładnie 57 lat, o czym sam informuje czytelnika swojej poezji:

„Dziesięć ja już pięcioleci,

Jeżeli się nie mylę, przeżyłem i siódmy

Rok już dalszy mego życia niebo słońca kręgiem toczy"3.

Autor znajduje się więc u schyłku życia, czego ma świadomość, a jednocześnie ubolewa nad faktem, iż nie uczynił niczego pożytecznego dla Boga w ciagu całego swego, dość długiego życia. Zadaje więc pytanie retoryczne: „Cóż pożytecznego ja w tak długim czasie dokonałem?"4, którego odbiorcą nie jest ani czytelnik, ani on sam, a zapewne sam Stwórca. $\mathrm{Z}$ owego pytania, w przekonaniu poety, rodzi się myśl o stworzeniu hymnów pochwalnych ku czci Boga, aby choć pod koniec ziemskiego żywota móc poprawić swoje położenie i zasłużyć na nagrodę wieczną. $Z$ nadzieją pisze więc:

„dusza grzesznica głupotę swą rzuci,

Niech choć słowem Boga chwali, gdy nie może zasługami!"s

Nie jest to jednak jedyny cel poezji Prudencjusza, który kreśli w Przedmowie do swych dzieł. Prudencjusz podkreśla bowiem, iż oprócz wartości pochwalnej swych dzieł zasadniczym jej celem jest walka $z$ herezją i wyjaśnienie wiary katolickiej, a także zniszczenie kultów pogańskich i rzymskich zabobonów. Rolę jego poezji można streścić więc słowami zawartymi w Praefatio:

„Niech z herezją walczy, wiarę katolicką niech wyjaśnia.

Kulty pogańskie depcze,

Zabobon twój, Rzymie, niech dotknie zagładą"6.

W niniejszym artykule skoncentrujemy się przede wszystkim na jednym z heksametrowych poematów dydaktycznych Prudencjusza, w których autor przedstawia i polemizuje ze znanymi mu herezjami - Liber Apotheosis. W utworze tym, poprzedzonym dwoma przedmowami, z których pierwsza (De Trinitate) traktowana jest jako samodzielny utwór poetycki, druga stanowi natomiast wprowadzenie do tematu całego poematu, poeta, polemizując z pogaństwem i różnymi herezjami, prezentuje katolicką naukę o Trójcy. Co ciekawe, pośród polemiki ze znanymi Prudencjuszowi herezjami wyróżnić możemy także atak na zwyczaje religijne i wierzenia Żydów, których autor traktuje na równi z odstępcami od wiary. Warto nadmienić, iż w utworze

${ }^{3}$ Prudentius, Praefatio operum 1-3, ed. M.P. Cunningham, CCL 126, Turnholti 1966, 1, thum. M. Brożek: Aureliusz Prudencjusz Klemens, Przedsłowie, w: Aureliusz Prudencjusz Klemens, Poezje, PSP 43, Warszawa 1987, 37.

${ }^{4}$ Tamże 6, CCL 126, 1, PSP 43, 37.

${ }^{5}$ Tamże 35-36, CCL 126, 2, PSP 43, 38.

${ }^{6}$ Tamże 39-41, CCL 126, 2, PSP 43, 38. 
Prudencjusza sam termin apotheosis - którym w Grecji określano dywinizację herosów, natomiast w Rzymie uznanie po śmierci człowieka za boga - odnosi się do samej boskości Chrystusa, której zaprzeczały różne herezje, negując

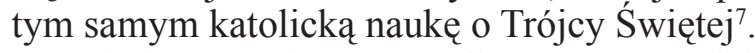

Jak już zostało zasygnalizowane, zasadniczym fragmentem dla prezentowanego tematu jest druga Przedmowa do Apotheosis, stanowiąca swoiste ostrzeżenie przed niebezpieczeństwem odstępstwa od prawdziwej wiary, a jednocześnie będąca wezwaniem skierowanym do chrześcijan, by zawsze kroczyli drogą wskazaną im przez Boga. Sam podmiot mówiący podkreśla, iż niezwykłą trudność stanowi odróżnienie prawdziwej wiary i kroczenie „ciasną drogą zbawienia"8, od wiary fałszywej, gdyż wiele jest krętych ścieżek i rozdroży gładzonych przez „odstępców błędne wykręty" . Łatwo jest także, według podmiotu mówiącego-poety, zboczyć z prawowiernej drogi, gdyż „boczne ze sobą krzyżują się odnogi, to tu, to tam się splatają"10, a krok w złą stronę wiedzie do ukrytej jamy wykopanej przez podstępnych wrogów ${ }^{11}$, którzy w ukryciu oczekują na przechodniów zbaczających z raz obranej ścieżki wiary. Zadaniem podmiotu-poety będzie więc opisanie owych błędnych herezji, uwidocznienie prawidłowych ścieżek wiary, które zagrażają chrześcijaństwu. Sam podmiot liryczny podkreśla, iż wśród mnogości występujących odstępstw - herezji przedstawi jedynie kilka, ,by wykład / trudny, źle podan, nie kaził katolickiej mowy"12. Podmiot kreuje się więc na nauczyciela prawdziwej wiary, na przewodnika w drodze do zbawienia, co podkreśla także dydaktyzm poetyckiej nauki Prudencjusza. W utworze tym, obejmującym 1054 heksametry, poeta broni bowiem idei odwiecznej boskości Chrystusa, przyjmując dogmat o Jego podwójnej naturze i uznając w Chrystusie-człowieku Chrystusa-Boga. Wśród negowanych przez niego herezji, w sposób bezpośredni, piętnowani byli patrypasjanie, zwolennicy teorii Prakseasza, według której Chrystus-człowiek był jedynie formą, pod którą Bóg-Ojciec przeszedł mękę i śmierć na krzyżu; sabelianie - głoszący modalistyczny pogląd, iż Trójca w Bogu jest troistością sposobów (modi) objawiania się jednego Boga; ebionici, zwani przez Prudencjusza homuncjonitami, zaprzeczający boskości Chrystusa i podkreślający Jego pochodzenie od Józefa; a w końcu manichejczycy, zwani przez poetę fantasmatykami, którzy twierdzili, iż Chrystus był jedynie zjawą (phantasma) i nie posiadał rzeczywistego ciała. Wśród heretyków, co zostało wcześniej wspomniane, poeta umieszcza także wyznawców judaizmu

\footnotetext{
${ }^{7}$ Por. S. Stabryła, Chrześcijański świat poezji Prudencjusza, Kraków 2011, 39.

${ }^{8}$ Prudentius, Liber Apotheosis. Praefatio II 5, ed. M.P. Cunningham, CCL 126, 74, thum. M. Brożek: Aureliusz Prudencjusz Klemens, Boskość Chrystusa, PSP 43, 84.

${ }^{9}$ Tamże II 8-9.

${ }^{10}$ Tamże II 9-10.

${ }^{11}$ Por. Tamże II 11-16, CCL 126, 74, PSP 43, 84-85.

${ }^{12}$ Tamże, Liber Apotheosis. Contra heresim quae Patrem passum adfirmat 1-2, CCL 126, 77,
} PSP $43,86$. 
- Żydów, pod adresem których kieruje największe obelgi i złorzeczenia. Dziwi jednakże, iż Prudencjusz swoją poezję skierował głównie przeciwko herezjom dawniejszym, z którymi polemizował chociażby Tertulian ${ }^{13}$, a brakuje potępienia arianizmu czy dość rozpowszechnionego w Galii i Hiszpanii pryscylianizmu. Prawdopodobnie spowodowane to było ówczesną sytuacją polityczno-społeczną i panowaniem proariańskiego cesarza Walentyniana II ${ }^{14}$.

2. Źródła herezji i obraz heretyka. W jaki sposób Prudencjusz określa jednak samą herezję? Podstawowym środkiem stylistycznym, który można odnaleźć $\mathrm{w}$ analizowanym poemacie, określającym odejście od wiary lub trwanie w niej, jest metafora drogi. Poeta w sposób jednoznaczny rozgranicza drogę prawdy, od krętych ścieżek niewiary. Herezja, według Prudencjusza, będzie więc zbłądzeniem, zejściem z właściwej ścieżki, podążaniem drogą nieprawości i zakłamania. Warto w tym miejscu przytoczyć najbardziej obrazowy i niezwykle sugestywny fragment, odnoszący się do herezji, który odnajdujemy w innym poemacie tego hiszpańskiego poety - Psychomachii. Upersonifikowana Herezja, stając w walce przeciwko Cnotom, przedstawia się w sposób następujący:

„Moje imię

Niezgoda, zwą mnie Herezją. Bóg mi różnoraki,

Mniejszy lub większy, podwójny, to znów pojedynczy;

Jak mi do gustu - jest płoną zjawą bezcielesną,

To znów, gdy z bóstwa chcę zakpić, wrodzoną nam duszą.

Mistrzem mym Belial, mym domem i krajem cały świat"15.

Herezja będzie więc stanowiła opozycję do prawdy - wiary w prawdziwego, trójjedynego Boga. Warto podkreślić, iż Prudencjusz wskazuje na pierwszorzędnego twórcę herezji, którego odnajduje w Belialu. Także parafrazując Jezusową przypowieść o pszenicy i kąkolu (por. Mt 13, 24-30) poeta wskazuje na szatana, który powoduje zachwaszczenie żyznego łanu Chrystusa („Wróg oszust, żyzny Chrystusa łan zachwaszcza / Złym kłosem, jakoby lepszym"16). On to, ojciec nieprawości, ,błądzących w ciemnościach [...] pcha na manowce i gubi" ${ }^{17}$. Drugorzędnym sprawcą herezji jest ludzka próżność i swawola myśli, która „Wszechmogącego istotę Boga szarpie obelżywymi sporami”18, a także, $\mathrm{z}$ inspiracji której:

\footnotetext{
${ }^{13}$ Por. I. Opelt, Die Polemik in der christlichen lateinischen Literatur von Tertulian bis Augustin, Heidelberg 1980.

${ }^{14}$ Według M. Brożka (Wstęp, w: Aureliusz Prudencjusz Klemens, Poezje, PSP 43, 25) możliwe jest, że Prudencjusz akceptował ascetyczne idee pryscylian, stąd nie wypowiada się bezpośrednio przeciwko ich poglądom.

${ }^{15}$ Por. Prudentius, Psychomachia 709-714, ed. M.P. Cunningham, CCL 126, 174-175, thum.

M. Brożek: Aureliusz Prudencjusz Klemens, Walka duszy, PSP 43, 155.

${ }^{16}$ Teże, Liber Apotheosis. Praefatio II 45-46, CCL 126, 75, PSP 43, 85.

17 Tamże II 41-42.

${ }^{18}$ Tamże II 19-20, CCL 126, 74, PSP 43, 85.
} 
„Wiarę na części wykrętne rozbierają,

Jak kto ma język zuchwalszy: Wikła się lub rozwiązuje kwestii węzły

Przez sylogizmy zawiłe"19.

Według Prudencjusza herezja nie ma również określonego terenu oddziaływania, ani konkretnego miejsca - może powstać zarówno na wschodzie, jak i zachodzie, nie bacząc ani na osobę, ani na sposób objawienia się Boga. Na straży prawowierności nauki, czystości przekazu, stoi Pismo Święte, które stanowi dla Prudencjusza źródło odniesienia i cel, ku któremu skłaniać się mają wyznawcy Chrystusa. Pismo stanowi więc trwały fundament wiary, niewyczerpane źródło przykładów, cytatów i wszelkiego rodzaju odwołań, które Prudencjusz konfrontuje z błędnymi naukami heretyków.

Jaki jest jednak obraz heretyka kreowany w Liber Apotheosis Prudencjusza? Na początku trzeba zaznaczyć, iż nie ma opisu fizycznego wyglądu. Trudno doszukiwać się w poetyckim tekście fragmentów mówiących bezpośrednio o wyglądzie zewnętrznym heretyka. Pewien obraz możemy jednak zbudować na podstawie epitetów, jakimi Poeta obdarza tych, którzy zboczyli z drogi wiary ortodoksyjnej. Tym samym Prudencjusz doskonale wpisuje się w stylistykę wczesnochrześcijańska, stosując jeden z najbardziej rozpowszechnionych środków wyrazu w polemice antyheretyckiej - inwektywę - rozumianą jako „gwałtowny, często imienny i obelżywy atak słowny lub pisemny, w prozie lub poezji, na osobę lub instytucje, które autor chce ośmieszyć i skompromitować, a nawet zniszczyć [...] z odpowiadającą im topiką retoryczną i ustalonym kanonem deprecjonujących epitetów" ${ }^{20}$. Prudencjusz stosuje najbardziej zajadły jej rodzaj - inwektywę antyheretycką - która ,jest nowym elementem literatury wczesnochrześcijańskiej, wzbogaconym obok tradycyjnych obelg (pies, bydlę, kłamca) treściami biblijnymi (plemię żmijowe, grób pobielany, wilk w owczej skórze, syn diabła, sługa szatana, zaraza diabelska, faryzeusz, Belzebub, Judasz) oraz przezwiskami negującymi moralną i intelektualną postawę odstępców religijnych oraz innowierców (zdrajca, łotr, apostata, profan, cudzołożnik prawdy, rebeliant Chrystusa, pseudochrześcijanin)"'21. Warto podkreślić, iż Prudencjusz stosując język inwektywy nie atakuje bezpośrednio danego heretyka (wyjątek stanowi Sabeliusz, którego wymienia z imienia ${ }^{22}$ ), ale całą społeczność osób wyznających wiarę niezgodną z wiarą chrześcijańską ${ }^{23}$. Dzięki temu nie deprecjonuje bezpośrednio danej osoby, ale gani przymioty wynikające z przynależności do danej grupy wyznawców. Dzięki temu nie tylko krytykuje poglądy niezgodne z nauką Chrystusa i dotyczące Chrystusa, ale podkreśla prawdziwość swoich słów o Chrystusie. Zgodnie wiec z antyczną zasadą w poemacie Prudencjusza pochwała łączy się w sposób bezpośredni

${ }^{19}$ Tamże II 21-24, CCL 126, 74-75, PSP 43, 85.

${ }^{20} \mathrm{~S}$. Longosz, Inwektywa, EK VII 413.

${ }^{21}$ Tamże, s. 414.

22 Por. Prudentius, Liber Apotheosis. Contra unionitas 178, CCL 126, 83, PSP 43, 90.

${ }^{23}$ Por. S. Longosz, Inwektywa chrześcijańska, SWP 534-535; Opelt, Die Polemik, s. 4-68. 
z naganą. Jej celem nie jest jednak popis kunsztem literackim, choć bez wątpienia Prudencjusz mógłby się tym szczycić, ale przede wszystkim podkreślenie i uwypuklenie głoszonych przez siebie tez. Poeta pragnie więc przedstawić naukę o Chrystusie porównując ją z poglądami głoszonymi przez heretyków po to, aby jeszcze skuteczniej trafić do odbiorców swojej poezji, a tym samym, co zostało wspomniane na początku niniejszego artykułu, jeszcze bardziej zasłużyć na chwałę życia wiecznego.

W omawianym utworze najczęściej pojawiającym się epitetem, stosowanym w odniesieniu w zasadzie do wszystkich heretyków, jest „pies”, w różnych konfiguracjach konotacyjnych: „pies bezecny”, „gorszy niż pies wojenny”, ,psi ród”. Same poglądy twórców i wyznawców herezji nazywa naukami żmii, błędnymi wykrętami, obelżywymi sporami, zdradliwymi krętactwami czy bredniami.

Najgorsze obelgi kieruje jednak pod adresem Żydów, których - jak wspomniano wcześniej - traktuje na równi z heretykami. Prudencjusz oskarża ich o zabicie Chrystusa, obchodzenie świąt, których symboliki nie znają i nie rozumieją, a także o atakowanie chrześcijaństwa - jedynej prawdziwej religii. Według poety są to osoby o twardym sercu, do którego nie dociera światło Prawdy, niemądrzy, zaślepieni, lud głuchy, który:

„słucha krzyku potwora miotanego szałem,

Wściekłego wrzasku szatana we wnętrzu człowieka,

I wierzy swoim, nieszczęsny!”24.

Wiarę Żydów określa mianem niemądrej i bluźnierczej, żydowskiej bredni.

Widzimy więc, iż zgodnie zresztą ze zwyczajami tamtej epoki, obraz heretyka malowany jest w czarnych barwach. Poprzez całą serię pejoratywnych osądów zbudować możemy charakterystykę heretyka, jako zuchwałego, nie zważającego na Pismo Święte odszczepieńca, którego działanie zmierza do unicestwienia prawdziwego przesłania Chrystusa. Piętnuje zwłaszcza fałsz, który jest główną mową heretyków. Prudencjusz podkreśla też ograniczoność intelektualną wszystkich, którzy podążają za twórcami herezji, nazywając ich wprost głupcami. Głównym więc celem, dla którego Prudencjusz podjął się napisania owego poematu, jest odparcie heretyckich poglądów na temat natury Chrystusa i podkreślenie tych elementów doktryny chrześcijańskiej, które stają w opozycji do błędnych nauk odszczepieńców. W Liber Apotheosis mamy więc do czynienia z potępianiem głównie błędnych myśli dogmatycznych, a same odniesienia moralno-ascetyczne stają się marginalne. Dojdą one do głosu w poemacie Hamartigenia, a także później w Psychomachii.

\footnotetext{
${ }^{24}$ Prudentius, Liber Apotheosis. Adversus Iudaeos 400-403, CCL 126, 91, PSP 43, 93.
} 
W twórczości Prudencjusza, co zostało pokazane w powyższym artykule, polemika $\mathrm{z}$ herezjami, a nawet walka z nimi, stała się jednym z kluczowych przesłań poetyckich autora. Prudencjusz pragnął podkreślić prawowierność nauki chrześcijańskiej poprzez kontrastowe zestawienie jej z nauką innowierców czy heretyków. $Z$ owego zestawienia można więc wysnuć wniosek, iż Prudencjusz aż nazbyt poważnie traktował swoją misję, a krytykowanie heretyków uznał za jeden z pierwszych celów swojej twórczości. Według poety, heretyk zawsze więc jest człowiekiem, który nie zasługuje na szacunek czy poważanie, a obraz jego osoby zawsze będzie negatywny.

\section{THE HERETIC'S IMAGE IN LIBER APOTHEOSIS OF AURELIUS PRUDENTIUS CLEMENS}

\section{(Summary)}

This article attempts to show the image of heretics in early Christian poetry. There are presented most characteristic speeches Aurelius Prudentius Clemens Spanish poet from the turn of the fourth and fifth centuries, contained especially in the Liber Apotheosis and concerning the problem of derogation from the orthodox faith. The sources of heresy are widely discussed as well as all specific vocabulary, which is mostly negatively marked.

Key words: Prudentius, heretic's image, poetry, Liber Apotheosis.

Slowa kluczowe: Prudencjusz, obraz heretyka, poezja, Liber Apotheosis.

\section{BIBLIOGRAFIA}

\section{Źródła}

Prudentius, Praefatio operum, ed. M.P. Cunningham, CCL 126, Turnholti 1966, 1-2, thum. M. Brożek: Aureliusz Prudencjusz Klemens, Przedstowie, w: Aureliusz Prudencjusz Klemens, Poezje, PSP 43, Warszawa 1987, 37-38.

Prudentius, Liber Apotheosis, ed. M.P. Cunningham, CCL 126, Turnholti 1966, 73-115, thum. M. Brożek: Aureliusz Prudencjusz Klemens, Boskość Chrystusa, w: Aureliusz Prudencjusz Klemens, Poezje, PSP 43, Warszawa 1987, 84-111.

Prudentius, Psychomachia, ed. M.P. Cunningham, CCL 126, 149-181, tłum. M. Brożek: Aureliusz Prudencjusz Klemens, Walka duszy, w: Aureliusz Prudencjusz Klemens, Poezje, PSP 43, Warszawa 1987, 137-160.

\section{Opracowania}

Brożeк M., Wstęp, w: Aureliusz Prudencjusz Klemens, Poezje, PSP 43, 7-36.

Coluins S.T., ,, The Apotheosis” of Prudentius, SE 9 (1957) 44-49. 
Fabian C., Dogma und Dichtung. Untersuchungen zu Prudentius „,Apotheosis”, Frankfurt am Main 1988.

Garuti G., Prudentius Apotheosis, Modena 2005.

Longosz S., Inwektywa chrześcijańska, SWP 530-537.

Longosz S., Inwektywa, EK VII 413-417.

Opelt I., Die Polemik in der christlichen lateinischen Literatur von Tertulian bis Augustin, Heidelberg 1980.

Padovese L., La cristologia di Aurelio Prudenzio Clemente, Roma 1980.

Rank R.G., ,, The Apotheosis” of Prudentius. A Structural Analysis, CF 20 (1966) 18-31.

StabryŁa S., Chrześcijański świat poezji Prudencjusza, Kraków 2011.

Widok N., Ortodoksja, herezja, schizma - wyjaśnienie pojęć, w: Ortodoksja, herezja, schizma w Kościele starożytnym, red. . F. Drączkowski - J. Pałucki - P. Szczur - M. Szram - M. Wysocki - M. Ziółkowska, Lublin 2012, 15-34. 